Gusejnova, Dina (2019) Changes of status in states of political uncertainty: towards a theory of derecognition. European Journal of Social Theory, 22 (2). pp. 272-292. ISSN 1368-4310

Accepted 4 May 2018

\title{
Changes of status in states of political uncertainty: towards a social theory of derecognition
}

This article examines existing versions of recognition theory, which is typically concerned with the enfranchisement of previously subaltern groups. Looking at several empirical case studies of social practices from twentieth-century history, it draws attention to the importance of status loss and the depreciation of value in periods of political rupture, particularly after the First World War. To conceptualise such examples, we need an expansion in the existing vocabulary of recognition theory. The article proposes ways to develop a theory of derecognition which might be used to guide empirical research on informal practices of political change.

Theories of recognition have been widely used to analyse processes of political legitimation. Recognition is seen as a practice of acknowledging a "partner in intersubjective interaction', as a result of which each subject or group is not only formally enfranchised but also achieves equal status in informal interaction (Honneth 1994). Practices of recognition enable societies to transcend forms of subjectivity grounded on a 'false, distorted, and reduced mode of being', and contribute to social equality by incorporating subaltern groups (Taylor 1982, 25). Due to its emphasis on diachronic aspects of social practice and noninstitutional types of agency, recognition theory is particularly suited to interdisciplinary empirical research involving historical studies of reforms, revolutions, and other forms of political rupture. In this article, I am interested in looking more closely at the conceptual vocabulary of recognition theory in 
this context. My hope is to expand this vocabulary in order to account for aspects of political change which have not been fully captured by existing approaches. By states of uncertainty I mean, broadly, a situation typically encompassing the lifetime of one generation, in which the status of governments, individuals or groups, and even of things and artefacts, is called into question. In these contexts, the value of statuses and artefacts remains uncertain over protracted periods of time. But in large sections of this article, I am going to be exploring more specific examples of uncertainty in the aftermath of the First World War and the Russian and German revolutions.

Like some other theoretical models which help explain changing forms of legitimation, such as social contract theory, recognition theory undermines primordialist or organicist conceptions of justice and power. In particular, recognition theorists aspire to provide an account of positive change which includes formerly inferior groups in the social process. However, due to this perspective, which naturally foregrounds the enfranchisement of subalterns, recognition theorists often disregard the fact that such forms of progressive transformation are often accompanied by 'negative' processes, including, notably, the political delegitmation of social groups and governments. It is these types of process that I am concerned with here. I suggest that they could be usefully captured through the concept of 'derecognition', which might form a theoretical complement to existing approaches in recognition theory.

The notion of derecognition [abrogatio, Aberkennung, déconnaissance] has not made a visible foray into social theory, even though, as I will discuss, the term itself has been used in a range of fields for a long time. Historians and other disciplines studying empirical cases of political rupture would benefit from using the concept more systematically. Conversely, some recent historical 
research into social practices in times of reform and revolution could also help refine the theoretical conceptualisation of recognition.

At times of rapid political change, which could be viewed on a wide spectrum from reform to revolution (see the discussion by Skocpol 1979/2015 or Dunn 1989), it is often the case that previously inferior, misrecognised groups gain acceptance. However, such moments of enfranchisement are also frequently accompanied by informal as well as legal action through which old privileges or statuses are publicly disavowed. In what follows, I shall provide a range of empirical and theoretical perspectives on practices of social transformation, including the abrogation of privileges, denaturalization, and discrediting previously respected individuals or groups - which, I suggest, can be described summatively with the term 'derecognition'. While most cases stem from the history of central and eastern Europe in the early to mid-twentieth century, the notion of derecognition as such is equally pertinent to similar examples from other geographical regions and periods. Before any empirical case studies can be discussed, however, I will first outline how recognition theory has developed, and where the concept of 'derecognition' might fit to develop it further.

\section{l \\ The scope of recognition theory}

Advocates of recognition approaches have highlighted their capacity to account for social conflict, which utilitarian or rational models of political change, such as social contract theory, tend to discount (most recently, this view of recognition theory has been advanced in Miller 2016; but see also the classic formulation in Honneth 1994). Whereas social contract theorists might examine a supposedly transformative contractual situation or a constitutive moment in 
which a government or entity is being empowered to represent a larger population, recognition theorists envisage status change as a set of repeatable informal processes. In this sense, theories of recognition are related both to socia contract theory and to constructivist theories of status and identity more broadly (see e.g. Rawls 1971 for a classic modern restatement of social contract theory; see also Searle 1990; Fraser 1989; Butler 1990; Appiah and Gutman 1996; Anderson 1983). Despite this emphasis on practice, recognition theorists have also been criticised for their limited account of cultural practices and group identities. For instance, some recognition theorists questioned the focus on intersubjective recognition in Honneth's model of the theory, and called for a need to recognise the multiplicity of cultures within polities (Taylor and Gutman 1994). Others insisted that any norm concerning intersubjective recognition ought to guarantee the preservation of some valued personal or group characteristics (Kalyvas 1999, 103; Zurn 2012, and see Honneth 2016 for a response). While such critiques are valid, their implications will not be covered in what follows, since my concern is with the more basic tenets of recognition theory that these criticisms do not touch upon, i.e. the focus on informal and repeated practice as opposed to single contractual events, imagined or real.

The history of recognition theory itself is illuminating for understanding how informal social interaction is conceptualised in this framework. Most twentieth-century theories of recognition are indebted to G.W.F. Hegel, particularly, the section of Hegel's Philosophy of Spirit, often translated as 'Lordship and Bondage', or, more accurately, as 'Lordship and Servitude' (Hegel 1807; for the reception, see Shklar 1991; Fraser 1999; Taylor 1994; Honneth 1994, Onuf 2013). The section is now one of the most frequently cited fragments of his work outside the discipline of Philosophy (Beiser 2011). Hegel's thinking about social change exposed the connection between forms of consciousness 
and progress in the real world by proposing a counterintuitive, yet compelling perspective on the capacity of human emancipation under conditions of social inequality. In this parable involving an imaginary lord and a bondsman, Hegel argued that in this unequal relationship, it is the bondsman and not the lord who has a more direct path to emancipation through self-consciousness. In legal terms, he is an inferior subject, but given his real experience of the world in this situation, which has to do with his use of labour and his material impact on the things that he is labouring upon, Hegel argues, the bondsman has the ability to access a fuller understanding of himself and others. By contrast, the lord's relationship to things in this world remains mediated through dependence on the bondsman, despite the fact that the bondsmain is subordinate to him in terms of his social status.

In discussing the relationship of people to each other and to things in the framework of his philosophy of history, Hegel transferred the discussion of intersubjective recognition from the legal and theological spheres to political philosophy and metaphysics. Recognition, in the widest sense, can apply as much to intersubjective situations, as it can to people and their own selves. Subsequently, this imaginary case has been developed more fully to show that the social practice of recognition in this intersubjective sense can be seen as a key instrument of human self-emancipation.

Before accounting for the nature of this reception, it is worth emphasising that Hegel himself used the word 'recognition' (Anerkennung) itself only rarely. Nonetheless, even if we cannot count 'recognition' among Hegel's personal keywords, it was certainly available to him as a concept, since it was a known juridical term (I use concept here in Koselleck's sense. Cf. Koselleck 1973/2004). European jurists and theologians before and after Hegel had used the concept of 'recognition' in the context of studies of Roman law, in the 
practice of civil law, in comparative anthropology, and, in theological literature, in relation to the psychological process of acknowledging one's sins (Bähr 1867; Leonhard 1894; Flörcke 1757). Moreover, the first generations of his readers were more interested in Hegel's concept of consciousness than recognition. Notably, for Marx, Hegel's understanding of labour as a source of selfconsciousness was threatened under conditions of modern industrial production, while the idea of the state, which for Hegel was the highest realisation of consciousness, turned out to be one of the sources of humanity's alienation from itself (Marx 1846/1932, Breckman 1999, 73 and passim). The theme of consciousness as a prerequisite of revolutions, which Hegel's theory had foregrounded, remained central for twentieth-century Marxists like Georg Lukács. According to Lukács ' elaboration on Marx 's stages theory of history, the degree of ' consciousness' of historical actors of their own situation differed in different ages: the capitalist age, for instance, was a more conscious age than the precapitalist one, where class consciousness has to be won or extracted. (Lukács 1923).

Thus recognition only became a key term for understanding Hegel's social thought retrospectively. Recognition theory as it is known today eventually developed most prominently in an Anglophone context in the decades following the Second World War, yet prior to this, it had been a prominent feature in the political thought of Russian philosophers engaged in rethinking revolutionary periods against the dominant narratives of orthodox Marxism between the 1920s and the 1940s. One of the key twentieth-century sources of thinking about recognition was the influential reading advanced by Alexandre Kojève in his interwar and wartime lectures in Paris (Kojève 1947, 2014). For Kojève, the central force of Hegel's theory was the focus on consciousness as an agent of history, and within it, his description of the desire 
to be recognised by others and to develop self-consciousness. Kojève's influential conceptualization of 'recognition' in French, American and postwar German thought allowed to rediscover Hegel's concept of conscousness independently from the idea of a class struggle, presenting it as an intersubjective process reflecting the human desire for identity (Taylor 1975; Butler 1987; Honneth 1994 and 2003; Jagentowicz Mills 1996; Pippin 2011). The idea of human agency in social transformation had changed, as Kojève's students proceeded to ascribe particular historical significance to the psychological history of revolutions, which they conceptualized as the moment when a recent object of misrecognition, or a non-recognised group, becomes a new subject capable of recognising others. Psychoanalytic schools of thought, such as that of Donald Winnicott and his followers (Winnicott 1965), drew on this concept in explaining the process of maturation by which a child acquires recognition from the mother. Gender theorists describe the recognition of the person of 'troubled' gender by the heterosexual majority.

A second important source for twentieth-century ideas of recognition drew its inspiration from Hegel's work on Aesthetics, though the reception of the concept of recognition in this area has evolved along quite separate lines from that of Hegel's political thought (Hegel 1823, 1998, 2014). One of the key figures in this context was the Russian philosopher Gustav Špet. 'In order for something to be socially real, socially valuable,' wrote Špet in 1936, 'the relevant society must recognize it. Recognition (come on, old man: Anerkennung) is a determinative [sic!] category of the social!' (Plotnikov 2013, 223, citing Špet 2005, 389). Working in revolutionary Russia, Špet had been part of a circle of avangarde theorists who wanted to bridge science and art in capturing the relationship of representation to reality in a revolutionary (Špet 1922). 
In the long run, however, Špet's work was forgotten in the wider international context of social theory. The next significant - and, for a wide range of reasons, much more widely known -- reception period of Hegel's Aesthetics in terms of recognition theory did not start until the work of Arthur Danto, who used it to develop a constructivist theory of art (Danto 1998, Danto 2014). However, in the end it was Kojève s interpretation which had the greatest influence on a number of subsequent social theorists, including Judith Butler, Charles Taylor and Robert Pippin. For them, the continued relevance of Hegel's concept lies in his emphasis on reason being a social process, rather than an ideal (Taylor and Gutman 1982, Butler 1990, Pippin 2011). What unites these later twentieth-century and early twenty-first century readings of Hegel is the observation that the chief role in bringing about revolutionary change belongs to the formerly inferior object as a decisive subject of historical change. The bourgeois becomes a revolutionary agent, the child becomes an adult, etc., and only when the former object of misrecognition has become an active subject can revolutionary change occur. At each historical moment when a new identity is recognised, 'recognition' is revealed as a driving force of history.

For the political philosopher Jeremy Waldron, the model for the gradual expansion of rights in the modern age is derived from the practice of ennoblement (Waldron 2012). The dignity and rights formerly applicable only to nobles were gradually extended to other citizens. Granting rights is a linear, expandable process of acknowledging social standing. Judith Shklar has argued similarly that the rights that constitute American citizenship ought more properly to be called 'emblems' or badges of honour derived from the entitlement to work and to vote (Shklar 2001). On this reading, all citizens become 'noble' when the Civil Code is introduced (leaving slightly unclear the question whether the same occurs through time in places where no Civil Code 
exists) (Whitman 2005). In this light, the public act of recognising always appears as an act of constructing equality, rather than destroying privilege or other social statuses. Another example of this is the introduction of the Napoleonic Code to states under his control, which extended rights previously granted only to privileged estates to all citizens of the state. Citizens were recognised as subjects of honour, previously an exclusive privilege of royalty and nobility. In the international sphere, the recognition of human rights to all humans independently of their former status as mere citizens (Sands 2016), the recognition of governments in exile (McGilvray 2010) or fledgling "nations in waiting' has generated another wave of interest in recognition as a mechanism of social transformation. (Bahcheli, Bartmann, and Srebrnik, 2004). The process of gradual inclusion of formerly misrcognised subjects into a community of citizens or states can thus also been captured by this term, making the concept of revolution and, within it, the struggle for state power, almost obsolete.

In sum, the concept of 'recognition' has come to describe social practices of enfranchisement as a key aspect of progress. In this context, Hegel's work on recognition in the fields of aesthetic representation and political philosophy has served as a key inspiration, but with few exceptions, these two strands of reception were evolving separately (the exceptions include Pippin 2011, Kompridis 2013, 2014). Secondly, despite Hegel's own, dialectical model of recognition, twentieth-century social theorists have focused almost exclusively on the 'inferior' subject as the real agent of change. Often related to ideas such as empowerment (Calvès 2009), the notion of recognition as it has developed since Hegel favours the focus on the formerly stigmatised, the recently undignified, the perspective of the former 'bondsman' over the former lord. Yet in historical experience, a key corrollary of social transformations includes negative processes, such as the stigmatization of the former stigmatizers, as an 
essential element in ensuring the equality of subjects thereafter. This is particularly reflected in the sphere of representation, including such instances as political cartoons or cultural propaganda in revolutionary periods where stigmatization or disavowal of privilege often loom larger than the celebration of a newly emancipated subject of history. 'Negative' processes follow a form of their own, which is more than just an 'inversion' of the positive or inclusionary direction. Charting the course of status destruction in its social and symbolic manifestations could help in thinking through the structural differences which are at the heart of lasting political transformations.

II

The concept of derecognition

To grasp processes which include elements of destruction or negation of status and value in times of political rupture, I propose to use the concept of 'derecognition'. The closest use of the concept in this sense comes from Political Theory and the theory of IR. Recently, theorists of international law have invoked the idea of a 'doctrine of derecognition' as a supposedly new mode of soft power conducive to non-violent regime change, suggesting that this would constitute a new paradigm for managing such situations (Auron 2013, as a critical complement to 'positive' recognition theory and IR, e.g. Greenhill 2008). As a practice of foreign relations, the term has previously appeared in the discussion of the status of China and Taiwan in the 1970s (Unger 1979, Kayes 1980). In the case of India, the term 'derecognition' has been applied to the incomplete loss of power of the Indian princes between the 1940s and the 
1970s, describing the abrogation of privileges in the princely states by the government of independent India in the 1970s (Richter 1971). The term was also used in the 1970s, when the United States derecognised Taiwan as a legitimate government of China (Unger 1979, Kayes 1980). In earlier historical periods, such interventions were conceptualised under different terms, such as the struggle against tyranny, humanitarian intervention, anarchism, and the fight against totalitarianism.

However, the notion of derecognising governments has also been present in the political discourses of the nineteenth and twentieth century. At its most categorical is the non-recognition of all governments by anarchist theorists and activists (Cf. Vincent 2011). Perhaps most famous in this regard are the words of the Russian anarchist Peter Kropotkin, according to whom the states of Europe of his time, "[l]ike worn-out old men, their skin shrivelled and their feet stumbling, gnawed at by moral sicknesses, incapable of embarking on the tide of new ideas' were living 'on credit on their past', and by doing so, merely hastened 'their ends by squabbling like aged gossips.' (Kropotkin 1992, 24). Categorically denying legitimacy to governments in their modern form also obviously remained an important tradition for Marx, and later for Lenin. But in the longer history of political theory, too, the idea of revoking the legitimacy of governments looked back on an older tradition: the discourses on the right of resistance to tyrants and illegitimate governments that was associated with Protestant and other dissident movements in early modern Europe (Cf. Baumgoldt 2007, 27-51; Schwoerer 1993).

Today, the notion of 'derecognition' as a practice is most widely invoked in financial theory and accounting (Opperman 2008, Subramani 2009, Law and Owen 2010), and bargaining (Korczynski and Ritson 2000). However, what I think is needed is to make the concept available for the description of a dual 
perspective on the process of status depreciation for individuals, as well as institutions and things. For example, it can be used to describe those who revoke others' rights, such as in cases when some groups or political communities cease to consider a government to be a legitimate holder of power and speak or act so as to make their views public. It can also capture the process and the experience of being derecognised, i.e. the subjective perception of becoming a 'former' person or sharing a lifeworld with one. More broadly, a social theory of 'derecognition' can be used to emphasise the significance of practices of shaming or discrediting former holders of power, or the withering away of privilege, which occurs in the shadow of more widely publicised acts of recognition, such as proclamations of or demands for rights. Conceptualised in this sense, the practice of derecognition nonetheless deserves special attention both from theorists and from empirical social scientists.

It is important to distinguish 'derecognition' as used above from seemingly similar terms which are widely used by recognition theorists, such as non-recognition, misrecogniton, or inferiorisation. These are all terms which theorists including Axel Honneth and Judith Butler have construed as the logical negative complements of 'recognition'. For instance, one could argue that women tend to be notrecognised as political subjects in premodern patriarchal societies. But they are not derecognised, because in these societies they have never been recognised in the first place. Equally, in some societies, an ethnic group could be misrecognised as inferior and subject to persecution. Societies that consider themselves modern tend to derecognise and thus delegitimate schemas that they consider traditional.

In terms of social ontology, derecognition could be described as the performance of acts (economic, legal, and intellectual) by which existing 
statuses (de facto as well as de jure) are conferred to new groups. The need for such a mechanism is most evident in civil and international criminal law, when a state deprives groups of rights that it had formerly granted them, or when a community of states no longer acknowledges another state as legitimate.

Among the earliest instances I could find of using the concept of 'derecognition' to describe the relationship between civil society and governments was an article by the Russian legal theorist and social activist Benjamin Mandel (1863-1931). Mandel lived in exile in Finland and later in Berlin after the revolution of 1917. Writing in a German journal specialising in comparative law, he spoke of the derecognition of the Soviet government by former subjects of the Russian empire (Mandel 1921). In the early to midtwentieth century, the term generally featured in literature covering a range of uncertain outcomes of revolutionary situations, such as the expatriation of populations and the status of governments in exile (Mandel 1921, Lauterpacht 1927, 1928 and 1945, Kelsen 1941). However, this usage then appears to have faded from attention, even though in the contexts of civil and constitutional law, the term 'derecognition' [Aberkennung] had been most developed in German legal theory to describe anomalous cases of denaturalization (See, for instance, Schnitzler 1871). Denaturalization, banishment and expatriation --- all known legal practices since at least the Roman Empire - were a common practice of the German princely states, applied to such known personalities as the Grimm brothers. (Martus 2009). (It has most recently been brought to popular attention in the discussion of the expatriation of Donald Trump's ancestor from Bavaria.) (Trump 1905/2017). In this context, the practice was especially problematised in Weimar constitutional debates (Goltsche 1922). 
Thus, the theme of repurposing former habits of privileged groups is particularly salient in Max Weber's lecture on Politics as a Vocation. Weber called the nobility a 'politically recyclable, non-estate based stratum' (Weber 1919). He was against the intervention of actual former nobles in modern politics, but he advocated the conversion of noble values into modern politics. In short, intellectuals who lived through revolutions and, to some extent, actively participated in establishing new regimes, like Max Weber and Georg Lukács, have left a far richer repository of concepts than the previous focus on the 'state' and on 'recognition' has allowed for. Thetheoretical interest in the consciousness of representatives of formerly governing elites was also shared by contemporary French historians in the interwar era. According to Maurice Halbwachs and Marc Bloch, the nobility was a prime example for the persistence of privileged social groups through the function of collective 'cadres' of memory, akin to the Platonic ,Idea' (Bloch 1939/1949). Maurice Halbwachs, writing in the 1920s, used the nobility as a prime example for arguing that social groups and classes were historically malleable and able to redefine themselves from within; social classes relatively were groups who äpossess, or who do not possess the kind of qualities most appreciated in their society' (Halbwachs 1925, 398).

The political and social thought of theorists who lived through several revolutions. Georg Lukács' s early reflections of 1923 is especially pertinent in this regard, since Lukács had the cases of Russia, Germany, and also Béla Kún's Hungary, before his eyes (Lukács 1923). As already mentioned, the central term for Lukács was consciousness, not recognition, but he paid particular attention to the place and subjectivity of social groups whose status was changing in revolutionary periods. Articulating a concern for the success of the revolutionary project, he observed how groups like the petty bourgeoisie, 
but also nobles who effectively should by now embrace the class consciousness of the bourgeoisie, will inadvertently act 'past their destiny' ['am Schicksal vorbei handeln'] - i..e. behave in ways which contradicts the logic of their supposed interests under a dialectical conception of progress (Lukács 1923, 70-72). This process is described in more detail in History and Class Consciousness. As he put it there, the 'consciousness' can in fact lag behind the historical process, so that a social group can think of itself as a "Knight of the Reformation era' and as that 'particular segment of society, which draws benefits from privileges'. Yet at the same time, as an estate, this segment can be "economically already entirely decomposed, its members can economically already belong to different classes [his emphasis] whilst retaining this (objectively unreal) ideological composure.' The reason for this was that the consciousness of an estate drew its legitimacy not from 'real, living economic unity' but a 'fixation upon a past society which had once legitimated its estatebased privileges.' (Lukacs 1923, 69-70).

In this broader sense of a social practice with political implications, the concept of 'derecognition' has particular pertinence for understanding changes of status times of political instability. As I suggest, the concept has an untapped potential for describing processes by which governments, groups, or individuals can recalibrate social statuses through a combination of formal and informal social practice. In the next and last section, I will turn to three areas in which it might usefully guide empirical understandings of these. 


\section{///}

Some empirical cases of derecognition

Twentieth-century history provides rich empirical material which can be usefully analysed through a focus on the relationship between repeated informal practices and actual change of social and political status. However, in many cases historians have discussed the relevant cases in separate contexts. I do not suggest that such contextual diversity should remain unaccounted for; however, using a common conceptual vocabulary to identify connections between a range of different empirical case studies which are not typically connected in the scholarship of their respective fields can contribute to a more granular understanding of the past. The examples I will discuss include the changing status of previously privileged social groups, either within a political community or transnationally; the shaming of governments by their own citizens; and the devaluation of artefacts previously recognised as valuable. Most examples can be contextualised within the history of central and eastern Europe in the early to mid-twentieth century, but these are also applicable to a wider range of situations.

The first case study pertains to the history of Europe's postimperial transformation in the twentieth century, particularly, to the revolutions in the Russian and German empires (1917-1922). Whilst proceeding with different degrees of radicalism, these tectonic shifts in the socioeconomic and political makeup of central and eastern Europe had some features in common too, and historians have recently highlighted these cross-imperial connections and parallels (Gatrell 2007, Gerwarth and Manela 2014, Smele 2016, Gusejnova 
2016, Smith 2017, Chernev 2017). One of these was the depreciation of status forms which had been considered privileged under the old regimes.

In most successor states to Europe's empires, Europe's old elites were divested of power (Reif 1994 and 2000, Wehler 1990). Despite different degrees of radicalism, the revolutionary and republican regimes emerging across a wide area reaching from the Urals to the Rhine did have some common policies. The Bolsheviks took an essentialist approach to people of formerly privileged status, suggeesting that being noble was nearly equivalent to doing something. Class could not simpy be removed like a cloak or a badge, even though social historians have subsequently shown how the Soviet regime ultimately ascribed class rather than identifying or discovering 'it' (cf. Fitzpatrick 1993). The relevant Bolshevik Decree of 10 November 1917 (23 November, according to the new calendar) abolished noble status together with several other estates associated with imperial governance: the clergy, the merchants and other privileges associated with life in the city, village dwellers, ethnic aliens or inorodtsy (particularly, Jews and the peoples of the Caucasus and Central Asia), and Finnish residents. Another example of Bolshevik practices of derecognition was its disavowal and violent persecution of Orthodox clergy. This prompted its leading figures to do the same in response, leading to such declarations as Patriarch Tikhon's Anathema of January 1918. ${ }^{1}$ Whilst forging a new identity which became the essence of Sovietness, this process also created a new social group, the lishentsy, or 'deprivees', meaning people deprived of their former status.

But the ripples of Bolshevik practices of derecognition transcended the boundaries of the emergent Soviet state. ,When I look at myself sociologically, the loss of my landed roots in particular has meant that there was not much left

\footnotetext{
${ }^{1}$ I am grateful to Miriam Dobson for drawing my attention to this point.
} 
but to preserve a figure that was, historically speaking, dead'(Keyserling 1948). Hermann Keyserling was a Baltic German of aristocratic lineage from the Russian Empire, who lost his Estonian estate and his title in the revolution of 1917 and later lectured and wrote about European identity from a base in Germany (Gusejnova 2015 and 2016). Cases like his can be of interest to historians as well as to social theorists for its discussion of the subjective experience of status change. The disavowal of the different privileges of nobles took a different legal form and had diverse symbolic representations in newly founded Czechoslovakia, in the Baltic states and in the German republic. Considering such examples to be case studies of 'derecognition practice' might be helpful in establishing a context for comparison, as well as drawing attention to the social and psychological context in which entire social strata were 'demoted'. These ranged from socially stigmatizing formerly superior groups to their physical extermination.

The notion of 'former people' as a legal-historical term had been around since the French Revolution, which brought into circulation the idea of the cidevant. The early Soviet ideologues developed this term through the concept of byvshye lyudi (i.e., 'people of the old regime'), applying it not only to nobles and royalty, but also to major landowners, clergymen, and merchants. Because the Soviet case was so radical, it was often considered in isolation from other European examples. However, linking this example to less violent practices of stigmatization might enable historians to utilise more transnational and comparative approaches of the European revolutions. The case of Keyserling, the Baltic Baron and Russian subject turned German citizen, is a good biographical example of the need for such perspectives. As someone whose original deprivation of status was associated with the Bolsheviks, he spent his 
subsequent life in the politically 'milder' climate of the German republican regime, before the Nazis enforced his renewed commitment to the Aryan race.

Using the term 'derecognition' across the borders of these different postimperial successor states would enable historians and theorists to capture an essential similarity behind the logic of these practices. Historians studying these regions have analysed not only the declining social status of aristocratic families, but also their adaptation to changing circumstances in the context of what Arno Mayer famously called the 'persistence of the old regime' (Mayer 81; Wehler 1990; Reif 2000; Conze and Wienfort 2004; Reif 2000, Wienfort 2006). What is interesting in this context is the relationship between economic and symbolic power and political power, but also, the subjective experience of those formerly privileged individuals and groups.

The revolutionary and republican regimes in Europe around 1917 developed a wide range of cultural practices aimed at diminishing the power of the social groups associated with the 'old regime'. In Germany, not one but twenty two revolutions occurred between 1917 and 1920, yet this period is not typically discussed as a 'German Revolution'. In addition to the Hohenzollerns, three kings (of the Wittelsbach, Wettiner, and Württemberg families), six grand dukes, five dukes, and seven princes lost their right to rule in their regional states. In Austria, in addition to a law dubbed the Habsburgergesetz, which outlawed specifically Habsburg claims to sovereignty in the dynasty's former heartland, the use of noble titles was outlawed. Nobles of Germanic background also lost power In Estonia and Poland, laws passed in 1920 and 1921 also abolished all noble titles, while in Lithuania and Latvia, references to noble privilege were simply omitted from their new constitutions.

The notion of 'derecognition' and its social implications could help to contextualise the debates of Weimar jurists on different sides of the political 
spectrum at a time of Germany's political transition from empire to republic. These jurists were concerned with building a new republican tradition, in which political allegiance to the German republic was to be married to the aim of achieving constitutional equality between German states, as well as the equality of privileges among German subjects (Goltsche 2010, Jacobsen and Schlink 2000, Kelly 2003 and 2004). In this context, one major constitutional debate revolved around the question of measures of expropriation against former princely rulers, as well as the status of their symbolic privileges (Schmitt 1926: 25-7, Wehler 1990, Reif 2000). When it comes to the subjective experience of losing privilege, for historians, the importance of non-conversion among the military elites of Europe's old empires is a important theme in recent historical research (Ziemann 2013, Matzerath and Marburg 2001). 'Noble consciousness', or Adelsbewusstsein, is now often studied based on primary sources based on individual or group biographies and family histories (Conze 2000; Malinowski 2003; Glassheim 2005).

As social scientists working with historical material, like Sofia Tchouikina, have shown, the process of making Soviet citizenship revealed a complex set of adaptation practices involving the conversion of a wide range of habitus and skills (Tchouikina 2017). Looking at twentieth-century Poland, the anthropologist Longina Jakubowska has observed that aristocratic identity persisted there in the linguistic and social juxtapositon of the term pan (the word for 'sir') with the term cham, and also through the distinction between the szlachta (the community of gentry) and the Jews. When pan became widely available to all educated Poles, the words cham and 'Jew' became markers of national identity. The notion of racial difference became important not only for the palingenetic myths of nations, but also for supranational types of racism 
such as the Nazi idea of the Aryan race. Each new type of 'sir' creates a psychological counter-image of a new 'boor.' (Jakubowska 2012).

Cultural historians working on this period of central and eastern European history might be interested in using the concept of 'derecognition' to analyse the removal of symbolism from streets and public buildings, which is associated with the privilege of former groups. This is of course best known through case studies such as the stripping of imperial symbolism in revolutionary Russia, which had been buit up around the imperial family particularly in the last century of its existence (Wortman 2000, on revolutionary symbolism, see Figes and Kolonitsky 1999, Bonnell 1996). Less well known is the less spectacular symbolic vocabulary of depreciating empire in Weimar Germany. There was debate, around 1918, whether to blow up the statues of Prussian kings adorning the Alley of Victory ['Siegesallee'] in Berlin, an unpopular project initiated by Wilhelm II to commemorate the defeat of France in the Franco-Prussian war of $1870 / 71$ and derisively called 'Alley of Puppets' by Berliners. It had only been completed in 1901 and included a genealogical parade of German rulers from Albrecht of Prussia, the last grand master of the Teutonic Order, to the Prussian King Wilhelm I. The revolutionary debate prompted the satirist Kurt Tucholsky to ask: 'What will come of the Siegesallee? Will they drive it out of the city towards the New Lake because it is too royalist, too autocratic and too monarchist? [...] Will they maintain the statues but place new heads on the same necks? [‥] And was all that learning of their names for my exams in vain?' (Tiger/Tucholsky 1918). Conceptualising these cases through the term 'derecognition' would enable historians to compare the postimperial transformation of European society in contemporaneous epochs and under different political regimes. 
Another set of historical case studies which could be usefully captured with the concept of 'derecognition' is the disavowal of governments by their own citizens as well as by the international community. Just as governments can derecognise their own citizens in the act of denaturalization, citizens as well as other societies and international powers can derecognise governments. They do this by means of soft power, diplomatic channels, or informal relations. Both of these aspects in the relationship between governments and people flared up as four empires crumbled in the wake of the First World War, and the treaties of Paris, Versailles, Trianon and Brest-Litovsk came to represent the rather shifting landscape constituting the international community. Hannah Arendt has famously described this moment as initiating a series of disappointments with the promises of the nation-state (Arendt 1951, 269, in 'The Decline of the Nation-state and the End of the Rights of Man'). But the crisis in recognition in the aftermath of imperial collapse implies a multiple sense of institutional failures: empires and their successors derecognised their subjects through acts of genocide and ethnic cleansing, as empires broke down their various constituent parts, comprising associations formed on political, ethnic, and religious grounds, derecognised the old elites, while non-continental powers such as Britain and the United States saw themselves confronted with a range of choices towards the new powers as well.

The aftermaths of the two World Wars, are a particularly fertile ground for studying notions of 'derecognition'. In the first instance, this was due to the heightened interest in the recognition of governments by legal theorists, historians, as well as diplomatic stafff involved in representing the old European powers in times of rapid political change (Lippman 1919, Lauterpacht 1927a, 1927b, and 1928, Mel'gunov 1929, Noble 1935; Lauterpacht 2013/1947, Epstein 1959, Shul'gin 1984). Anti-Bolshevik parties involved in the Russian Civil War, 
intellectuals and military personnel associated with the counterrevolutionary 'White Movement' repeatedly denounced the emergent Bolshevik regime, informally derecognising what was de facto, and eventually also de jure, a sovereign power (Katzer 1999, Wiederkehr 2007). From this basis, they published journals and other widely read works in print, in which they not only denounced Russia's revolutionary regime, but exposed its corruptibility (Raeff 1990). In the absence of a legal heir to the monarchy, and living in exile, they nonetheless held on to organisations such as the Zemgor, the regional types of self-government which disintegrated with the empire.

Yet another context in which the term 'derecognition' might apply to the relationship between governments and civil societies in Weimar and Nazi Germany, highlighting some of the connections in the social histories of both regimes which are often sidelined. In the Weimar period, a legal initiative known as the 'Radbruch Draft', associated with the work of the jurist Gustav Radbruch, spelled out in detail the legal foundations of the possibility of civil litigation against police injustice and criminal behaviour that can be ascribed to state representatives (Goltsche 2010). A similar moment of 'derecognition' by citizens of govenments can be observed in the case of populations who were exiled or expatriated due to the rise of Nazi Germany. Using the concept of 'The Other Germany' in the 1930s and 1940s, inspired by the Weimar-era liberal and pacifist newspaper Das andere Deutschland [The other Germany] (founded in 1925), exiles rallied support for what could be described as an informal Germany in exile, or a 'humanist front' (Berendsohn 1949).

This cultural alternative to a derecognised state could be usefully compared to the emergence of governments in exile representing French, Polish or Czechoslovak dissidents with varying degrees of diplomatic and institutional formality (on governments in exile, cf. Oppenheimer 1942, more recently, Shain 
and Linz 1995, Conway and Gotovitch 2001, McGilvray 2010). The concept of 'derecognition' would be capacious enough to allow scholars to evaluate the relative impact of cultural, diplomatic and military powers in enabling or disabling the recognition of governments by their own as well as by foreign constituents.

To mention a third case briefly, the ideological depreciation of previously valuable cultural artefacts could also be considered as a practice of derecognition. Once again, the period concerned is the series of transformations in the structure of legitimation in central and eastern Europe, from the collapse of its empires to the defeat of the Third Reich. Such a broad conceptualisation of a century of extremes, which has been made popular again recently by the historiographical perspectives offered by Timothy Snyder and others (Snyder 2010, Gerwarth and Horne 2012). It could be fruitfully deepened by looking at the function of cultural policy in the period of radical social transformation through the lens of derecognition. Key institutions such as the early Academy for the Study of the Arts in Soviet Russia, the Reichskulturkammer in Nazi Germany, and other bodies, were responsible for backing to the construction of new ideologies.

The work of the aforementioned Russian philosopher Gustav Špet might serve as a biographical example here. Despite being at the forefront of efforts to unify Marxist-Leninist perspectives on aesthetics in the early years of Soviet rule, he eschewed the conventions of orthodox Marxism-Leninism and instead became an object of the new regime's 'derecognition' of bourgoeois philosophical doctrines. Špet's name made it to the infamous list of undesirable philosophers that Lenin ordered out of the country in 1922 on the 'Philosopher's steamer'. Due to Špet's refusal to emigrate, however, he not only failed to find a hearing in western Europe until the twenty-first century, but also precluded a 
reception in Russian contexts. Špet was executed among mass arrests in 1937 , and his work has only recently received detailed attention from historians (Plotnikov 2013). But considered in context, Špet's work on Hegel's concept of recognition provides a fascinating insight into the practice of derecognition at the level of science and culture.

The styles and approaches in the visual arts, intellectual history and music, which were endorsed were intimately connected with ideas about old and new regimes (Plotnikov 2013, or, for a primary source, Ziegler 1938). Rather than viewing the emergence and later persecution of the cultural avantgardes in Soviet Russia, Weimar and later Nazi Germany, as separate instances, the concept of derecognition could help conceptualise the social process by which such collective decisions to depreciate entire directions of thought and culture were made or became acceptable. This understanding of the role of informal social practice in providing political legitimacy has been more common in studies of the Cold War, but it is yet to be linked conceptually to our understanding of the earlier twentieth century (Cf. Scott-Smith and Krabbendam 2003, and others, including Gusejnova 2016).

What I have suggested here is that thinking conceptually about a variety of social practices as instances of 'derecognition' can reveal previously unseen connections in European history. The empirical examples can add texture and complexity to the established theories of recognition. It is worth thinking about the fact that Hegel himself, despite writing in the wake of the French Revolution, ultimately ended up celebrating the Prussian state -- the very opposite of a revolutionary polity. What remained crucial for those influenced by his work was the connection between consciousness and conceptions of progress. But what 
has faded from attention among social theorists, if not philosophers (e.g. Pippin 2011), was Hegel's own comprehension of the link between aesthetic and political representation on the one hand, and social transformation on the other.

Even though the above examples stem from European case studies, as I have indicated, the term 'derecognition' can be equally fruitful in examining the process of alternative sovereignty formation beyond Europe. Examples might include the process of decolonisation, notably in India (Copland 1997), or the social practices emerging in republican China (Harrison 2000). Enriching the conceptual vocabulary of recognition theory with attention to the social practices of derecognition could contribute to the development of a critical theory of modern ideologies (Bourdieu 1972, Honneth 1986, Burke 2005, Freeden 2013). Such a theory of derecognition could help to conceptualise the importance of informal practices for political status changes, and do so in a way that would be politically agnostic towards the ideology prevalent in a particular society. In this way, it might also provide a useful heuristic for empirical work on various historical phenomena connected to social change. 


\section{Acknowledgements}

I am grateful to Richard Westerman, Mara Mairin, Leigh Claire La Berge, and Nicholas Gaskill, as well as to John Searle and members of the Berkeley Social Ontology Group, for their comments on an older draft of this paper. I also thank Mary Vincent, Miriam Dobson and Alexis Papazoglou for their constructive feedback on a later draft.

\section{References}

Anderson, Benedict (1983) Imagined Communities. London: Verso, 1983. Appiah, Kwame Anthony and Amy Gutmann (Eds.) (1996) Color Conscious: The Political Morality of Race. Princeton. N.J.: Princeton University Press, 1996. Arendt, Hannah (1951) The Origins of Totalitarianism. New York: Harcourt Brace Jovanovich.

Auron, Danny (2013) 'The Derecognition Approach: Government, Illegality, Recognition, and Non-Violent Regime Change', George Washington International Law Review, 45, 443-51.

Bahcheli, T., Bartmann, B., Srebrnik, H.F. (Eds.), 2004. De facto states: the quest for sovereignty. London: Routledge.

Bähr, Otto (1867) Die Anerkennung als Verpflichtungsgrund. Cassel: Wigand. Baumgold, Deborah (2010) Contract Theory in Historical Context: Essays on Grotius, Hobbes, and Locke. Leiden: Brill.

Beiser, Frederick (2011) 'Hegel and Hegelianism', The Cambridge History of Nineteenth-Century Political Thought, eds. Gareth Stedman Jones and Gregory Claeys. Cambridge: Cambridge University Press, 110-146.

Berendsohn, Walter A. (1949) Die humanistische Front. Einführung in die deutsche Emigranten Literatur, Vol. 1. Zurich: Europa-Verlag.

Bloch, Marc (1939) La société féodale. Les classes et le gouvernement des hommes. Paris: Albin Michel.

Bonnell, Victoria (1996) 'The Leader's Two Bodies: a Study in the Iconography of the Vozhd', Russian History, 23:1, 113-35.

Bourdieu, Pierre (1972/2013), Outline of a Theory of Practice. Cambridge: Cambridge University Press.

Breckman, Warren (1999) Marx, the Young Hegelians, and the Origins of Radical Social Theory: Dethroning the Self. Cambridge and New York: Cambridge University Press.

Burke, Peter (2005) History and social theory, 2nd ed. Ithaca, NY: Cornell University Press.

Butler, Judith (1990) Gender Trouble. Feminism and the Subversion of Identity. New York: Routledge. 
Calvès, Anne-Emmanuèle (2009) ' "Empowerment » généalogie d'un concept clé du discours contemporain sur le développement', Revue Tiers Monde, 200, 735-49.

Chernev, Borislav (2017) Twilight of empire: the Brest-Litovsk Conference and the remaking of East-Central Europe, 1917-1918. Toronto: University of Toronto Press.

Conway, Martin, and José Gotovitch, eds. (2001) Europe in Exile: European Exile Communities in Britain, 1940-1945. New York: Berghahn Books.

Conze, Eckart (2000) Von deutschem Adel: die Grafen von Bernstorff im zwanzigsten Jahrhundert. Stuttgart: Deutsche Verlags-Anstalt.

Conze, Eckart and Monika Wienfort, eds. (2004) Adel und Moderne: Deutschland im europäischen Vergleich im 19. und 20. Jahrhundert; [Tagung, die im März 2002 am Zentrum für Interdisziplinäre Forschung (ZiF) der Universität Bielefeld stattgefunden hat]. Cologne: Böhlau. Copland, Ian (1997) The Princes of India in the Endgame of Empire, 19171947. Cambridge and New York: Cambridge University Press.

Danto, Arthur C. (1998) 'The End of Art: A Philosophical Defense', History and Theory, 37:4 (December), 127-43.

Danto, Arthur C., and Lydia Goehr (1995/2014) After the End of Art: Contemporary Art and the Pale of History. Princeton, NJ: Princeton University Press.

Dunn, John (1989) Modern revolutions: an introduction to the analysis of a political phenomenon. Cambridge and New York: Cambridge University Press. Epstein, Fritz (1959) 'Studien zur Geschichte der „Russischen Frage” auf der Pariser Friedenskonferenz von 1919', Jahrbücher für Geschichte Osteuropas, 7:4, 431-78.

Figes, Orlando and Boris Kolonitsky (1999) Interpreting the Russian Revolution. The Languages and Symbols of 1917. New Haven: Yale University Press.

Fitzpatrick, Sheila (1993) 'Ascribing Class: The Construction of Social Identity in Soviet Russia', The Journal of Modern History, 65, 745-770.

Fraser, Nancy (1989) Unruly practices: Power discourse and gender in contemporary social theory. Minneapolis: University of Minnesota Press.

Fraser, Nancy (1999) Social Justice in the Age of Identity Politics: Redistribution, Recognition, and Participation. London: Sage.

Freeden, Michael (2013) The Political Theory of Political Thinking: the Anatomy of a Practice. Oxford: Oxford University Press.

Gatrell, Peter (2013) The Making of the Modern Refugee. Oxford: Oxford University Press. 
Gatrell, Peter (2007) 'Introduction: World Wars and Population Displacement in Europe in the Twentieth Century', Contemporary European History, 16, 415-426.

Gerwarth, Robert and Erez Manela, eds. (2014) Empires at War: 1911-1923. Oxford: Oxford University Press.

Gerwarth, Robert, and John Horne, eds. (2012) War in Peace: Paramilitary Violence in Europe after the Great War. Oxford: Oxford University Press Goltsche, Friederike (2010) Aberkennung von Bürgerlichen Ehrenrechten. Der Entwurf Eines Allgemeinen Deutschen Strafgesetzbuches von 1922.

Berlin/New York: Walter de Gruyter.

Greenhill, Brian (2008) 'Recognition and Collective Identity Formation in International Politics', European Journal of International Relations 14:2, June, 343-68.

Gusejnova, Dina (2016) European Elites and Ideas of Empire, 1917-1957. Cambridge: Cambridge University Press.

Gusejnova, Dina (2015) 'Keyserling's keywords: the challenges of translating Europe', Comparativ, 2, October, 29-45.

Halbwachs, Maurice (1925) Les cadres socieaux de la mémoire. Paris: Félix Alcan.

Harrison, Henrietta (2000) The Making of the Republican Citizen: Political Ceremonies and Symbols in China, 1911-1929. Oxford and New York: Oxford University Press.

Hegel, Georg Wilhelm Friedrich (1807) System der Wissenschaft. Erster Teil, Phänomenologie des Geistes. Bamberg and Würzburg: Jos. Ant. Goebhardtsche Buchhandlungen.

Hegel, Georg Wilhelm Friedrich (1998) Vorlesungen über Die Philosophie Der Kunst (Berlin 1823), after the notes of Heinrich Gustav Hotho. Hamburg: Meiner.

Hegel, Georg Wilhelm Friedrich (2014) Lectures on the Philosophy of Art: The Hotho Transcript of the 1823 Berlin Lectures. Oxford: Oxford University Press. Hegel, Georg Wilhelm Friedrich, Philosophie Der Kunst Oder Ästhetik: Nach Hegel, Im Sommer 1826; Mitschrift Friedrich Carl Hermann Victor von Kehler, eds. Annemarie Gethmann-Siefert and Bernadette Collenberg-Plotnikov.

Munich: W. Fink..

Honneth, Axel (1994/2016) Kampf um Anerkennung: zur moralischen Grammatik sozialer Konflikte. Frankfurt am Main: Suhrkamp. Honneth, Axel (2004) 'Recognition and Justice: Outline of a Plural Theory of Justice', Acta Sociologica 47, 351-364.

Honneth, A., Kocyba, H., Schwibs, B. (1986) 'The Struggle for Symbolic Order an Interview with Pierre Bourdieu', Theory, Culture \& Society, 3, 35-51. 
Jacobsen, Arthur and Bernhard Schlink, eds. (2000) Weimar: A Jurisprudence of Crisis. Berkeley and Los Angeles: University of California Press.

Jagentowicz Mills, Patricia, ed. (1996) Feminist Interpretations of G.W.F. Hegel, Re-reading the Canon. University Park, PA: Pennsylvania State University Press.

Kalyvas, Andreas (1999) 'Critical Theory at the Crossroads: Comments on Axel Honneth's Theory of Recognition', European Journal of Social Theory, 2, 99-108.

Katzer, Nikolaus (1999) Die Weiße Bewegung in Russland:

Herrschaftsbildung, Praktische Politik Und Politische Programmatik Im

Bürgerkrieg. Cologne: Böhlau.

Kayes, Jonathan M., 'The Republic of China and Derecognition. The Effects on Taiwain', Journal of International Affairs, 34:1, 191-94.

Kelly, Duncan (2004) 'Carl Schmitt's Political Theory of Representation', Journal of the History of Ideas, 65, 113-34.

Kelly, Duncan (2003) The State of the Political: Conceptions of Politics and the State in the Thought of Max Weber, Carl Schmitt, and Franz Neumann. Oxford: Oxford University Press.

Keyserling, Hermann (1948). Reise durch die Zeit. Vaduz: Liechtenstein Verlag. Kojève, Alexandre (1947/2014) Introduction à la lecture de Hegel: leçons sur la Phénomenologie de l'esprit professées de 1933 à 1939 à l'École des Hautes Études, ed. Raymond Queneau. Paris: Gallimard.

Kompridis, Nikolas (2013) 'Recognition and Receptivity: Forms of Normative Response in the Lives of the Animals We Are', New Literary History, 44:1, 124.

Kompridis, Nikolas (2014) The Aesthetic Turn in Political Thought. New York: Bloomsbury Academic.

Koselleck, Reinhart (1973/2004) 'Historical Criteria of the Modern Concept of Revolution', in idem, Futures Past. New York: Columbia University Press, 4358.

Kropotkin, Peter (1992) Words of a Rebel, transl. G. Woodcock. Montreal: Black Rose Books.

Lauterpacht, Hersch (1947/2013) Recognition in International Law.

Cambridge: Cambridge University Press.

Lauterpacht, Hersch (1945) 'Recognition of Governments: I', Columbia Law Review, 45, 815-64.

Lauterpacht, Hersch (1928) 'Revolutionary Activities by Private Persons

Against Foreign States', The American Journal of International Law, 22, 105-30. 
Lauterpacht, Hersch (1927a) 'Private Law Sources and Analogies of

International Law'. London and New York: Longmans, Green \& Co.

Lauterpacht, Hersch (1927b) 'Revolutionary Propaganda by Governments',

Transactions of the Grotius Society, 13, 143-64.

Leonhard, Rudolf (1894) Institutionen des Römischen Rechts. Ein Lehrbuch.

Leipzig: Veit \& Komp.

Lippman, Walter (1919) 'The Peace Conference', Yale Review, 8:4, July, 721.

Lukács, Georg (1923) Geschichte und Klassenbewußtsein. Berlin:Malik.

Malinowski, Stefan (2003) Vom König zum Führer: sozialer Niedergang und

politische Radikalisierung im deutschen Adel zwischen Kaiserreich und NS-Staat. Berlin: Akademie-Verlag.

Mandel, B. (1921) 'Die Rechte der politischen Emigranten und das deutschrussische Abkommen vom 6. Mai 1921', Blätter für vergleichende Rechtswissenschaft und Volkswirtschaftslehre XVI, 157-74.

Martus, Steffen (2009) Die Brüder Grimm: Eine Biographie. Berlin: Rowohlt. Marx, Karl (1846/1932),Die deutsche Ideologie“, in Marx-Engels

Gesamtausgabe, pt. I. vol. V. Berlin: Marx-Engels Institute Moscow, 1932.

Mayer, Arno J. (2010) The Persistence of the Old Regime: Europe to the Great War. London: Verso.

McGilvray, Evan (2010) A Military Government in Exile: the Polish governmentin-exile, 1939-1945. Solihull: Helion.

Mel'gunov, Sergey P. (1929), N. V. Čaikovski v gody grazdanskoj voiny.

Materialy dlia istorii russkoi obsčestvennosti 1917-1925 [NV. Caikovski

in the years of civil war. Materials for a history of Russian civil society 1917-1925], 2 vols. Paris: Rodnik.

Miller, Jason (2016) 'The Role of Aesthetics in Hegelian Theories of Recognition', Constellations, 23:1, March, 96-109.

Noble, George Bernard (1935) Policies and Opinions at Paris, 1919: Wilsonian Diplomacy, the Versailles Peace, and French Public Opinion. New York: Macmillan.

Onuf, Nicolas (2013) 'Recognition and the constitution of epochal change', International Relations, 27, 121-140.

Oppenheimer, F.E. (1942) 'Governments and Authorities in Exile', The American Journal of International Law, 36:4, 568-595.

Pippin, Robert B. (2011) Hegel on Self-Consciousness: Desire and Death in the Phenomenology of Spirit. Princeton: Princeton University Press.

Plotnikov, Nikolaj (2013) 'Hegel at the GAKhN: Between Idealism and Marxism-on the Aesthetic Debates in Russia in the 1920s', Studies in East European Thought, 65:3-4, December, 213-25. 
Raeff, Marc (1990) Russia Abroad: A Cultural History of the Russian

Emigration, 1919-1939. Oxford and New York: Oxford University Press.

Rawls, John (1971) A Theory of Justice. Cambridge, Mass: Harvard University Press.

Reif, Heinz (1994) Ostelbische Agrargesellschaft im Kaiserreich und in der Weimarer Republik: Agrarkrise - junkerliche Interessenpolitik Modernisierungsstrategien. Berlin: Akademie-Verlag.

Reif, Heinz (1999) Adel Im 19. Und 20. Jahrhundert. Munich:Oldenbourg Sands, Philippe (2016) East West Street: on the Origins of Genocide and Crimes Against Humanity. London: Weidenfeld \& Nicolson.

Schmitt, Carl (1926) Unabhängigkeit der Richter, Gleichheit vor dem Gesetz und Gewährleistung des Privateigentums nach der Weimarer Verfassung. Ein Rechtsgutachten zu den Gesetzentwürfen über die Vermögensauseinandersetzung mit den früher regierenden Fürstenhäusern. Berlin: Walter de Gruyter.

Shain, Yossi, Juan J. Linz, and Lynn Berat (1995) Between States: Interim Governments and Democratic Transitions. Cambridge: Cambridge University Press.

Schnitzler, Leo (1871) Die Aberkennung der Staatsangehörigkeit nach den Bestimmungen des Reichsgesetzes über die Erwerbung und den Verlust der Bundes- und Staatsangehörigkeit vom 1. Juni 1870. Cologne: Kölner VerlagsAnstalt und Druckerei.

Schwoerer, Lois G. (1993), 'The right to resist: Whig resistance theory, 16881694', in Political Discourse in Early Modern Britain, Nicholas Phillipson and Quentin Skinner, eds. Cambridge: Cambridge University Press, 232-53.

Searle, John (1990), The Construction of Social Reality. New York: Free Press. Sewell, William (1999) 'The concept(s) of culture', in Beyond the Cultural Turn: New Directions in the Study of Society and Culture, eds. Victoria Bonnell, Lynn Hint and Richard Biernacki. Berkeley: University of California Press, 35-62.

Shklar, Judith (2001) American Citizenship: the Quest for Inclusion.

Cambridge, Mass.: Harvard University Press.

Shul'gin, Vasily (1984) The Years: Memoirs of a Member of the Russian Duma, 1906-1917. New York: Hippocrene Books.

Skocpol, Theda (1979/2015) States and Social Revolutions: a Comparative Analysis of France, Russia, and China. Cambridge: Cambridge University Press.

Smele, Jonathan (2016) The "Russian" Civil Wars, 1916-1926: Ten Years that Shook the World. London: Hurst. 
Smith, Steven (2017) Russia in Revolution: an Empire in Crisis, 1890 to 1928.

Oxford: Oxford University Press.

Snyder, Timothy (2010) Bloodlands: Europe Between Hitler and Stalin. New York: Basic Books.

Špet, Gustav (1922) Estetičeskie fragmenty. Moskva: Kolos.

Špet, Gustav (2005) Žizn v pis'makh. Epistoljarnoe nasledie, ed. Tatiana Šcedrina.

Moscow: Rosspen.

Subramani, R. Venkata (2009) Accounting for investments. Singapore: Wiley \& Sons.

Taylor, Charles (1975/2005) Hege/Cambridge: Cambridge University Press.

Taylor, Charles, and Amy Gutmann (1982) Multiculturalism: Examining the

Politics of Recognition. Princeton, NJ: Princeton University Press.

Tchouikina, Sofia (2017) Les gens d'autrefois: la noblesse russe dans la société soviétique. Paris : Belin.

Tiger, Theobald aka Kurt Tucholsky (1918) 'Bruch', Ulk, 13 December, 50.

Trump, Friedrich (1905./2017) 'The Emigrants', reprinted in Harpers Magazine, March, https://harpers.org/archive/2017/03/the-emigrants/. Accessed 30 January 2017.

Unger, Leonard, 'Derecognition Worked', Foreign Policy, 36, Autumn, 105-21.

Vincent, K. Steven (2011) 'Visions of stateless society', in The Cambridge History of Nineteenth-Century Political Thought, eds. Gareth Stedman-Jones and Gregory Claeys. Cambridge: Cambridge University Press, 433-76.

Waldron, Jeremy (2012) Dignity, Rank, and Rights. Oxford and New York: Oxford University Press.

Weber, Max (1919) ,Politik als Beruf', in idem, Geistige Arbeit als Beruf. Vier Vorträge vor dem Freistudentischen Bund. Zweiter Vortrag. Munich and Leipzig: Duncker \& Humblot.

Wiederkehr, Stefan (2007) Die Eurasische Bewegung: Wissenschaft Und Politik in Der Russischen Emigration Der Zwischenkriegszeit Und Im Postsowjetischen Russland. Cologne: Böhlau.

Winnicott, Donald (1990) The Maturational Processes and the Facilitating

Environment: Studies in the Theory of Emotional Development. London: Karnac books.

Wortman, Richard S. (2000) From Alexander // to the Abdication of Nicholas /l. Princeton: Princeton University Press.

Ziegler, Hans Severus (1938) Entartete Musik, eine Abrechnung, Exhibition catalogue, British Library, 7901.bb.57.

Ziemann, Benjamin (2013) Gewalt im Ersten Weltkrieg: Töten - Überleben Verweigern. Essen: Klartext. 
Zurn, Christopher F. (2005) 'Recognition, Redistribution, and Democracy: Dilemmas of Honneth's Critical Social Theory', European Journal of Philosophy, $13(89-126)$. 